Nebojša D. Nikolić ${ }^{\star}$, Vesna M. Maksimović², Goran Branković, ${ }^{3}$ Predrag M. Živković ${ }^{4}$, Miomir G. Pavlović ${ }^{1}$

${ }^{1}$ University of Belgrade, ICTM-Department of Electrochemistry, Belgrade, Serbia, ${ }^{2}$ University of Belgrade, Vinča Institute of Nuclear Sciences, Belgrade, Serbia, ${ }^{3}$ University of Belgrade, Institute for Multidisciplinary Research, Belgrade, Serbia, ${ }^{4}$ University of Belgrade, Faculty of Technology and Metallurgy, Belgrade, Serbia
Scientific paper

ISSN 0351-9465, E-ISSN 2466-2585

UDC:620.186/187

doi: $10.5937 / Z a s M a t 1802256 \mathrm{~N}$

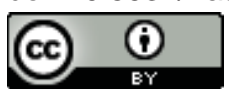

Zastita Materijala 59 (2)

256 - 264 (2018)

\title{
Correlation between crystal orientation and morphology of electrolytically produced powder particles: analysis of the limiting cases
}

\begin{abstract}
Abstract. Lead and nickel powder particles were produced by the processes of electrolysis and characterized by scanning electron microscope (SEM). The X-ray diffraction (XRD) analysis of the produced particles was done. Morphologies of $\mathrm{Pb}$ and Ni particles were correlated with their crystal structure at the semi quantitative level by determination of "Texture Coefficients" (TC) and "Relative Texture Coefficient" (RTC). The two dimensional (2D) dendritic particles of lead of different degree of ramification were obtained by the potentiostatic regime of electrolysis from the nitrate, acetate and hydroxide electrolyte. The spongy-like particles of nickel constructed from holes formed of the detached hydrogen bubbles and surrounded by cauliflower-like agglomerates of approximately spherical grains (the honeycomb-like structure) were obtained by the galvanostatic regime of electrolysis from the chloride electrolyte. Although crystallites were dominantly oriented in the (111) plane in both $\mathrm{Pb}$ and Ni particles, analysis of the XRD data showed different preferred orientation of the formed particles. All types of $\mathrm{Pb}$ dendritic particles showed the strong (111) preferred orientation, while crystallites of Ni in the spongy-like particles were almost random oriented. The obtained results were discussed following Winand's classification of metals on the normal, intermediate and inert metals based on their values of the exchange current density, melting point and overpotential for hydrogen evolution reaction.

Keywords: electrolysis, powder, lead, nickel, SEM, XRD.
\end{abstract}

\section{INTRODUCTION}

Electrolysis is one of the most often used methods for synthesis of metals in the powder form [1]. The advantages of this method in relation to the other methods, such as atomization processes, melt spinning, rotating electrode process (REP), mechanical and chemical processes, are: low equipment and product costs, one-step, environmentally friendly, formation the high purity products, etc. [2]. The electrolytically produced powders are high purity which can be easily sintered and pressed $[3,4]$. The electrolytically produced powders belong to the group of disperse or irregular deposits which spontaneously fall from the electrode surface or are removed from it by tapping or on some similar way $[1,3]$.

\footnotetext{
*Corresponding author: Nebojša D. Nikolić

E-mail: nnikolic@tmf.bg.ac.rs

Paper received: 30. 03. 2018.

Paper accepted: 15. 04. 2018.

Paper is available on the website: www.idk.org.rs/journal
}

Various powdered forms can be obtained by electrolysis: dendrites, wires or needles, spongylike, flakes, fibrous and cauliflower-like forms. The shape and size of produced particles depends on the conditions and regimes of electrolysis, the presence of additives, hydrogen evolution as parallel reaction, and the nature of metals.

The most important conditions of electrolysis affecting the final shape and size of powder particles are: kind and composition of electrolytes, concentrations of depositing ions and supporting electrolyte, the type of working electrode, temperature and time of electrolysis $[1,3]$. The both constant (potentiostatic and galvanostatic) and periodically changing (pulsating overpotential (PO), pulsating current (PC) and reversing $(R C)$ ) regimes of electrolysis are used for powder production $[1,3,5,6]$. The addition of additives can strongly affect morphology of the particles, and it usually occurs through inhibition of dendritic growth [7, 8]. Also, inhibition of dendritic growth occurs as a result of vigorous hydrogen evolution as the second reaction during metal electrolysis [9-12]. 
Regarding values of the exchange current density $\left(j_{0}\right)$, melting point and overpotential for hydrogen discharge, metals are classified into the three classes [13]:

(a) Class I, so-called normal metals: Pb, Sn, TI, $\mathrm{Cd}, \mathrm{Hg}, \mathrm{Ag}$ (simple electrolytes), $\mathrm{Zn}$. These metals are characterized by low melting points and high exchange current densities $\left(j_{0}>1 \mathrm{~A} \mathrm{dm}^{-2} ; j_{0}\right.$ is the exchange current density). Also, they show high overpotentials for hydrogen discharge.

(b) Class II, intermediate metals: $\mathrm{Cu}, \mathrm{Au}, \mathrm{Ag}$ (complex electrolytes). These metals are characterized by moderate melting points, medium exchange current densities $\left(j_{0}\right.$ in the interval from $10^{-2}$ to 1 $\mathrm{A} \mathrm{dm}^{-2}$ ) and lower hydrogen overpotentials.

(c) Class III, inert metals: Fe, Co, Ni, Mn, Cr, Pt. These metals have high melting points, low exchange current densities and very low hydrogen overpotentials. For this class of metals $j_{0}$ is between $10^{-2}$ and $10^{-12} \mathrm{~A} \mathrm{dm}^{-2}$.

In spite of numerous investigations concerning electrolytic metal powder production, there was no a data correlating morphology of particles with their crystal structure. In past investigations, the larger contribution of metal crystallites oriented in the (111) plane in relation to the other planes is usually reported [14-16], but without any deeper analysis of this correlation. However, it was recently reported [17] that crystal structure modification of electrodeposited Ag thin films by application of ultrasound achieved the strong consequence on some of properties of produced films, such as brightness, hardness, etc. Simultaneously, it was established [18, 19] the existence of correlation between morphology of $\mathrm{Ag}$ particles, obtained by various methods of synthesis (electrolysis and chemical reduction) and under various conditions of electrolysis, and their crystal structure at the semi quantitative level, with the strong consequences on some of decisive properties characterizing behaviour of powders as collection of particles like the specific surface area (SSA). Regarding the significance of existence of this correlation, we continue this type of investigation analysing the limiting cases of metals from electrochemical point of view - lead (Class I) and nickel (Class III).

\section{EXPERIMENTAL}

Lead in the powder form was electrodeposited potentiostatically at an overpotential of $90 \mathrm{mV}$ with a quantity of the electricity of $0.50 \mathrm{~mA} \mathrm{~h} \mathrm{~cm} \mathrm{~cm}^{-2}$ from the following electrolytes:

(a) $0.10 \mathrm{M} \mathrm{Pb}\left(\mathrm{NO}_{3}\right)_{2}+2.0 \mathrm{M} \mathrm{NaNO}$ (the nitrate electrolyte),

(b) $0.10 \mathrm{M} \mathrm{Pb}\left(\mathrm{CH}_{3} \mathrm{COO}\right)_{2}+1.5 \mathrm{M} \mathrm{NaCH} \mathrm{NOO}_{3} \mathrm{CO}$ $+0.15 \mathrm{M} \mathrm{CH}_{3} \mathrm{COOH}$ (the acetate electrolyte), and (c) $0.10 \mathrm{M} \mathrm{Pb}\left(\mathrm{NO}_{3}\right)_{2}+2.0 \mathrm{M} \mathrm{NaOH}$ (the hydroxide electrolyte).

All electrodepositions were performed in an open cell at the room temperature. Doubly distilled water and analytical grade chemicals were used for the preparation of the solutions for electrodeposition of lead. All electrodepositions were performed on vertical cylindrical copper electrodes. The geometric surface area of copper electrodes was $1.0 \mathrm{~cm}^{2}$. Reference and counter electrodes were of pure lead. The counter electrode was lead foil with $0.80 \mathrm{dm}^{2}$ surface area and placed close to the cell walls. The reference electrode was wire of lead whose tips were positioned at a distance of about $0.2 \mathrm{~cm}$ from the surface of the working electrodes. The working electrodes were placed in the centre of cell, at the same location for each experiment.

Nickel powder was electrodeposited from a solution containing $1 \mathrm{M} \mathrm{NH} \mathrm{NH}_{4} \mathrm{Cl} 0.7 \mathrm{M} \mathrm{NH}_{4} \mathrm{OH}$ and $0.1 \mathrm{M} \mathrm{NiCl}$ at a constant current density of 1265 $\mathrm{mA} \mathrm{cm}{ }^{-2}$. Ni electrodeposition was performed at the room temperature in the cylindrical glass cell of the total volume of 1 I with cone shaped bottom of the cell in order to collect powder particles in it. Working electrode was a Ni wire of the diameter of $0.18 \mathrm{~cm}$, with the total surface area of $2.3 \mathrm{~cm}^{2}$ immersed in the solution and placed in the centre of cell. Cylindrical Ni foil placed close to the cell walls was used as a counter electrode providing excellent current distribution in the cell. All solutions were made from distilled water and analytical grade chemicals. The time of removal of the powder from the electrode surface was 15 min.

Morphologies of $\mathrm{Pb}$ and $\mathrm{Ni}$ particles were characterized by the technique of scanning electron microscope (SEM) using TESCAN Digital Microscope, model VEGA3 (Pb) and Philips, model XL30 (Ni).

X-ray diffraction (XRD) analysis of $\mathrm{Pb}$ and $\mathrm{Ni}$ particles was carried out using the Rigaku Ultima IV diffractometer. The preferred orientation of produced $\mathrm{Pb}$ and $\mathrm{Ni}$ particles was estimated by determination of the "Texture Coefficient", TC $(h k l)$ and the "Relative Texture Coefficient", RTC $(h k l)$ in the following way $[18,20]$ :

The ratio of reflection intensity $(h k l)$ to the sum of all intensities of the recorded reflections, $R(h k l)$, (in \%) is calculated according to Eq. (1):

$$
R(h k l)=\frac{I(h k l)}{\sum_{\mathrm{i}}^{4} I\left(h_{\mathrm{i}} k_{\mathrm{i}} l_{\mathrm{i}}\right)} \times 100
$$

where $I(h k l)$ is the reflection intensity $(h k l)$, in cps, and $\sum_{\mathrm{i}}^{4} I\left(h_{\mathrm{i}} k_{\mathrm{i}} l_{\mathrm{i}}\right)$ is the sum of all intensities of the recorded reflections, in cps, for the particles being considered. 
The "Texture Coefficient", TC(hkl), for every $(h k l)$ reflection is defined by Eq. (2):

$$
T C(h k l)=\frac{R(h k l)}{R_{\mathrm{s}}(h k l)}
$$

where $R_{\mathrm{s}}(h k l)$ is defined in the same way as given by Eq. (1), but is related to the Ag standard (40783). This coefficient gives the accurate quantitative information about the absolute reflection intensity.

Finally, the "Relative Texture Coefficient", $R T C(h k l)$ is defined by Eq. (3):

$$
R T C(h k l)=\frac{T C(h k l)}{\sum_{\mathrm{i}}^{4} T C\left(h_{\mathrm{i}} k_{\mathrm{i}} l_{\mathrm{i}}\right)} \times 100
$$

The $R T C(h k l)$ coefficient defines the reflection intensity $(h k l)$ relative to the standard (included in the $T C$ values).

\section{RESULTS AND DISCUSSION}

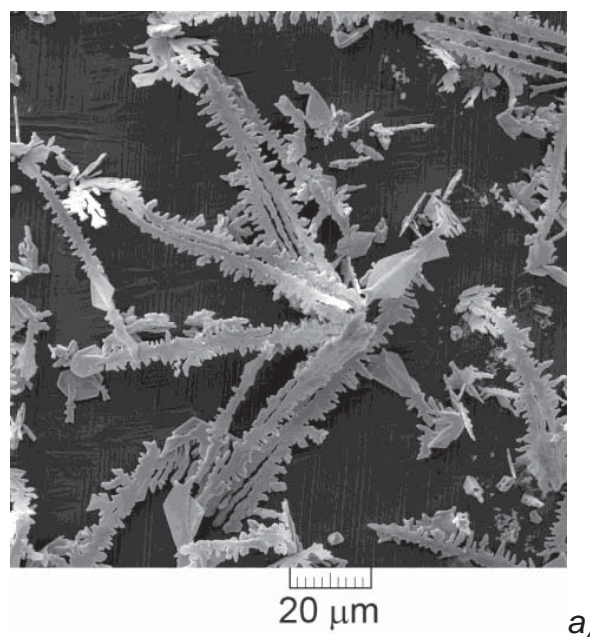

a)

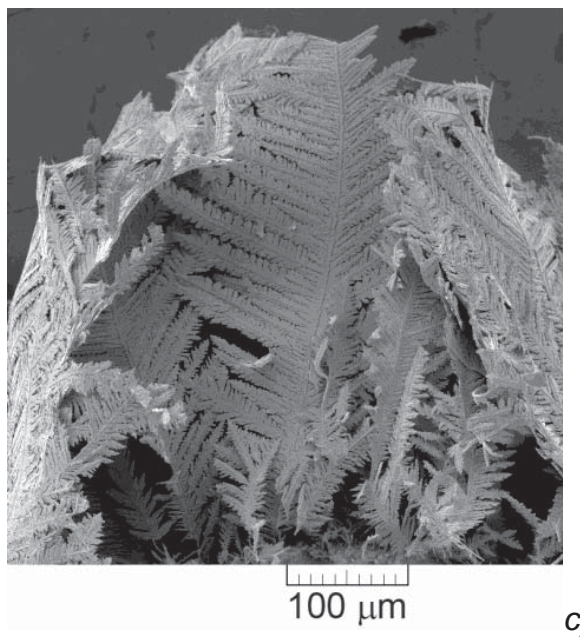

3.1. Morphological and crystallographic analysis of lead powder particles

Figure 1 shows morphologies of $\mathrm{Pb}$ powder particles obtained at an overpotential of $90 \mathrm{mV}$ from the nitrate (Fig. $1 \mathrm{a}$ and b), acetate (Fig. 1c and d) and hydroxide (Fig. 1e and f) electrolytes. For all electrolytes, the overpotential of $90 \mathrm{mV}$ was outside the plateau of the limiting diffusion current density in the zone of the fast increase of current density with increasing the overpotential after the inflection point [21-23]. From Fig. 1, it can be seen that the two dimensional (2D) dendritic particles were formed from all three electrolytes, but with the considerable difference among them. The dendrites obtained from the acetate (Fig. 1c and d) and the hydroxide (Fig. 1e and f) electrolytes were more branchy structures than those obtained from the nitrate electrolyte (Fig. 1a and b). This ramification of dendrites was a consequence of complex formation of $\mathrm{Pb}^{2+}$ ions with acetate and hydroxyl ions [21-24].

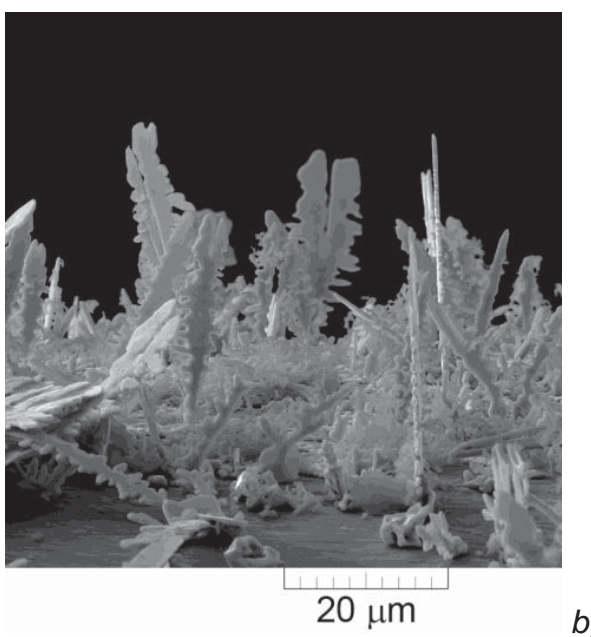

b)

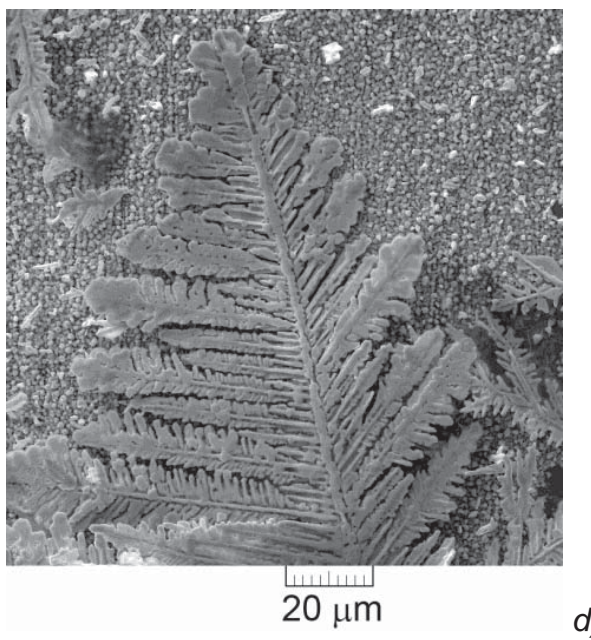

d) 

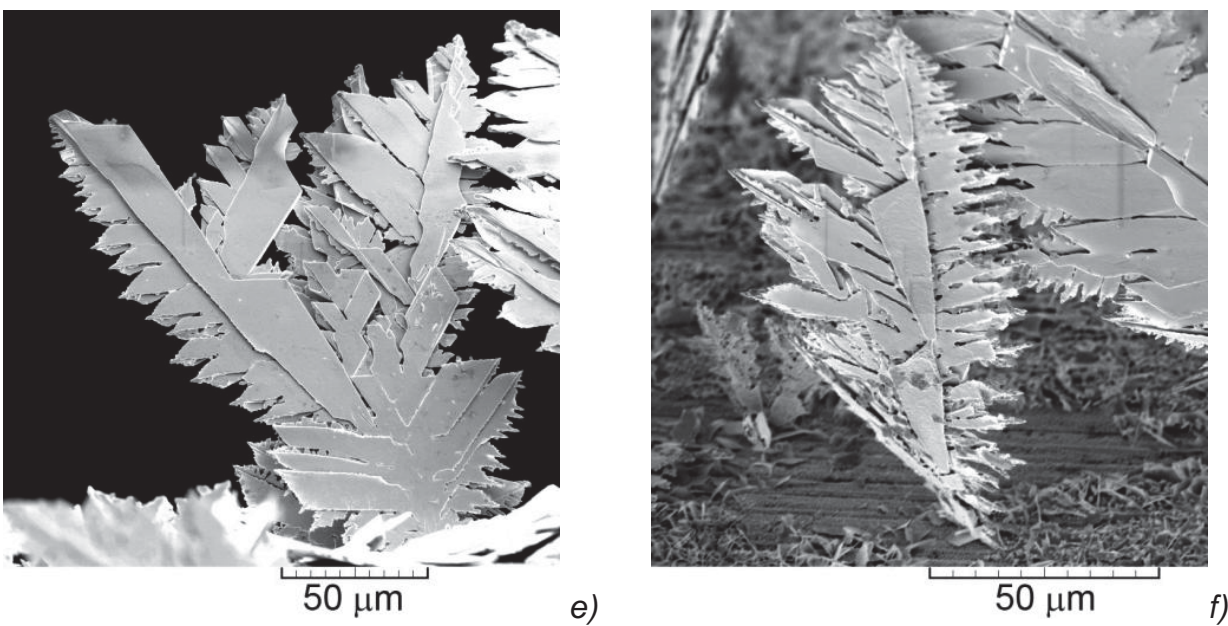

Figure 1. Morphologies of $\mathrm{Pb}$ dendrites obtained by potentiostatic electrolysis at an overpotential of $90 \mathrm{mV}$ from: a) and b) the nitrate electrolyte, c) and d) the acetate electrolyte, and e) and f) the hydroxide electrolyte

Slika 1. Morfologije dendrita olova dobijenih potenciostatskom elektrolizom na prenapetosti od $90 \mathrm{mV}$ iz: a) i b) nitratnog, c) i d) acetatnog, i e) i f) hidroksilnog elektrolita

The XRD patterns of the obtained particles are shown in Fig. 2. The diffraction peaks observed at $2 \theta$ angles of $31.3^{\circ}, 36.3^{\circ}, 52.2^{\circ}, 62.1^{\circ}, 65.2^{\circ}, 77.0^{\circ}$, $85.4^{\circ}$ and $88.2^{\circ}$ clearly indicate that $\mathrm{Pb}$ crystallizes in face centered cubic (fcc) lattice. At the first sight, it is clear that $\mathrm{Pb}$ crystallites were dominantly oriented in the (111) plane, with the considerably larger ratio in this plane than in the other planes.

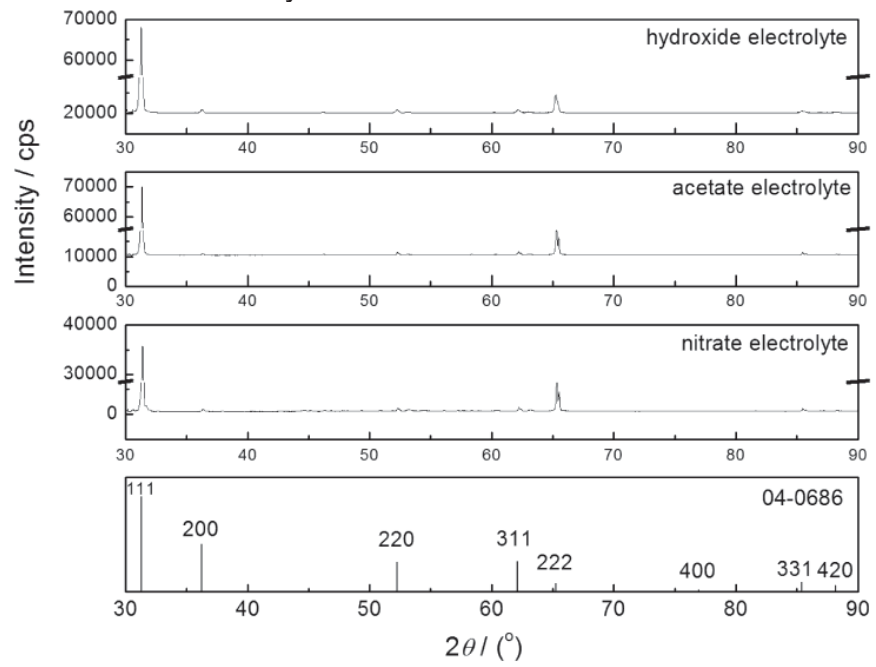

Figure 2. The XRD patterns of $\mathrm{Pb}$ particles obtained by potentiostatic electrolysis at an overpotential of $90 \mathrm{mV}$ from the nitrate, acetate and hydroxide electrolytes, and $\mathrm{Pb}$ standard (04-0686)

Slika 2. Rendgenogrami olovnih čestica dobijenih potenciostatskom elektrolizom na prenapetosti od 90mV iz nitratnog, acetatnog, i hidroksilnog elektrolita, i Pb standard (04-0686)

The preferred orientation of the obtained particles can be determined on two ways: (a) the fast estimation based on a determination of the peak intensity ratios $[18-20,25]$, and b) more precise estimation based on a determination of "Texture coefficient", $T C(h k l)$, and the "Relative texture coefficient", RTC $(h k l)$ [18-20]. The peak intensity ratios including four the largest reflections $(111) /(200), \quad(111) /(220)$ and $(111) /(311)$ for the examined electrolytes together with $\mathrm{Pb}$ standard (04-0686) are summarized in Table 1 . The considerably larger ratios than those for $\mathrm{Pb}$ standard indicate the existence of the strong preferred orientation in the (111) plane. 
Table 1. Ratios of intensities of diffraction peaks for the analyzed $\mathrm{Pb}$ powders and for $\mathrm{Pb}$ standard

Tabela 1. Udeli intenziteta difrakcionih pikova za analizirane prahove olova i za $\mathrm{Pb}$ standard

\begin{tabular}{|l|c|c|c|}
\hline \multirow{2}{*}{$\begin{array}{l}\text { The type } \\
\text { of powder } \\
\text { particles }\end{array}$} & \multicolumn{3}{|c|}{ Ratio of intensities } \\
\cline { 2 - 4 } & $(111) /(200)$ & $(111) /(220)$ & $(111) /(311)$ \\
\hline $\begin{array}{l}\text { The nitrate } \\
\text { electrolyte }\end{array}$ & 35.5 & 27.9 & 26.7 \\
\hline $\begin{array}{l}\text { The acetate } \\
\text { electrolyte }\end{array}$ & 58.3 & 41.8 & 39.3 \\
\hline $\begin{array}{l}\text { The } \\
\text { hydroxide } \\
\text { electrolyte }\end{array}$ & 50.1 & 49.8 & 50.1 \\
\hline $\begin{array}{l}\text { Pb standard } \\
\text { (04-0686) }\end{array}$ & 2.0 & 3.2 & 3.1 \\
\hline
\end{tabular}

The TC(hkl) and RTC $(h k l)$ coefficients calculated from the XRD data (Fig. 2) using Eqs. (1)-(3) are given in Table 2. The values of $T C(h k l)$ coefficients larger than 1 indicate the existence of the preferred orientation in the determined plane [20]. Regarding $R T C(h k l)$ coefficients, in the range $30-90^{\circ}$ eight reflections is situated ( $\mathrm{Pb}$ standard: 04-0686; Fig. 2), and then, the RTC(hkl) values larger than $12.5 \%$ indicate the existence of the preferred orientation. It is very clear from Table 2 that there is a strong preferred orientation in the (111) plane, i.e. that $\mathrm{Pb}$ crystallites are predominately oriented in the (111) plane.

Table 2. Texture calculations for $\mathrm{Pb}$ powders obtained by electrolysis from various electrolytes (the nitrate electrolyte - NIT, the acetate electrolyte - AC, the hydroxide electrolyte - HYD, s - Pb standard)

Tabela 2. Proračuni teksture za prahove olova dobijenih elektrolizom iz različitih elektrolita (nitratni elektrolit - NIT, acetatni elektrolit - AC, hidroksilni elektrolit - HYD, s - Pb standard)

\begin{tabular}{|c|c|c|c|c|c|c|c|c|c|c|}
\hline \multirow[b]{2}{*}{$\begin{array}{c}\text { Plane } \\
(h k l)\end{array}$} & \multicolumn{3}{|c|}{$R($ in $\%)$} & \multirow[b]{2}{*}{$\begin{array}{c}R_{\mathrm{s}} \\
\text { (in \%) }\end{array}$} & \multicolumn{3}{|c|}{$T C$} & \multicolumn{3}{|c|}{ RTC (in \%) } \\
\hline & $R_{\mathrm{NIT}}$ & $R_{\mathrm{AC}}$ & $R_{\mathrm{HYD}}$ & & $T C_{N I T}$ & $T C_{A C}$ & $T C_{\mathrm{HYD}}$ & $R T C_{\mathrm{NIT}}$ & $R T C_{A C}$ & $R T C_{\mathrm{HYD}}$ \\
\hline (111) & 72.8 & 77.0 & 85.2 & 41.5 & 1.88 & 1.86 & 2.05 & 40.6 & 26.4 & 40.8 \\
\hline$(200)$ & 2.05 & 1.32 & 1.70 & 20.7 & 0.099 & 0.064 & 0.082 & 2.1 & 0.90 & 1.6 \\
\hline$(220)$ & 2.61 & 1.84 & 1.71 & 12.9 & 0.20 & 0.14 & 0.13 & 4.3 & 2.0 & 2.6 \\
\hline$(311)$ & 2.73 & 1.96 & 1.70 & 13.3 & 0.21 & 0.15 & 0.13 & 4.5 & 2.1 & 2.6 \\
\hline (222) & 16.1 & 15.1 & 8.10 & 3.7 & 1.21 & 4.08 & 2.19 & 26.1 & 57.8 & 43.6 \\
\hline$(400)$ & 0 & 0 & 0 & 0.80 & 0 & 0 & 0 & 0 & 0 & 0 \\
\hline (331) & 2.17 & 1.76 & 1.11 & 4.1 & 0.53 & 0.43 & 0.27 & 11.5 & 6.1 & 5.4 \\
\hline$(420)$ & 1.54 & 1.02 & 0.48 & 3.0 & 0.50 & 0.33 & 0.17 & 10.9 & 4.7 & 3.4 \\
\hline
\end{tabular}

\subsection{Morphological and crystallographic analysis of nickel powder particles}

Figure 3 shows nickel powder particles obtained at a current density of $1265 \mathrm{~mA} \mathrm{~cm}^{-2}$ from chloride electrolyte. From Fig. 3, it can be seen that the spongy-like particles are obtained by this galvanostatic regime of electrolysis. The main characteristics of these particles are holes originating from the detached hydrogen bubbles surrounded by cauliflower-like agglomerates of the approximately spherical Ni grains. On the basis of these characteristics, it is clear that the spongy-like particles have the typical honeycomb-like structure $[1,26]$.

The XRD pattern of the obtained particles together with $\mathrm{Ni}$ standard (04-0850) is shown in Fig. 4. The observed reflections at the $2 \theta$ angles of $44.5^{\circ}, 51.8^{\circ}, 76.4^{\circ}$ and $92.9^{\circ}$ confirms that $\mathrm{Ni}$ crystallize in face centered cubic (fcc) lattice. Similar to the XRD patterns obtained for $\mathrm{Pb}$, crystallites of $\mathrm{Ni}$ were dominantly oriented in the (111) plane, but with the larger ratios of crystallites oriented in the (200), (220) and (311) planes. The preferred orientation of the obtained particles was estimated by determination of peak intensity ratios (the fast estimation) and by determination of $T C(h k l)$ and $R T C(h k l)$ coefficients (the precise estimation). In the case of $\mathrm{Ni}$, since four reflections is situated in the range $30-95^{\circ}$, then the $R T C(h k l)$ values larger than $25 \%$ indicate the existence of the preferred orientation. The results of the estimation of the preferred orientation on these two ways are summarized in Tables 3 (the fast estimation) and 4 (the precise estimation).

Table 3. Ratios of intensities of diffraction peaks for the analyzed Ni powder and for Ni standard

Tabela 3. Udeli intenziteta difrakcionih pikova za analiziran prah nikla i za Ni standard

\begin{tabular}{|l|c|c|c|}
\hline \multirow{2}{*}{$\begin{array}{l}\text { The type } \\
\text { of powder } \\
\text { particles }\end{array}$} & \multicolumn{3}{|c|}{ Ratio of intensities } \\
\cline { 2 - 4 } & $(111) /(200)$ & $(111) /(220)$ & $(111) /(311)$ \\
\hline $\begin{array}{l}\text { the chloride } \\
\text { electrolyte }\end{array}$ & 2.9 & 4.6 & 4.8 \\
\hline $\begin{array}{l}\text { Ni standard } \\
\text { (04-0850) }\end{array}$ & 2.4 & 4.7 & 5.0 \\
\hline
\end{tabular}



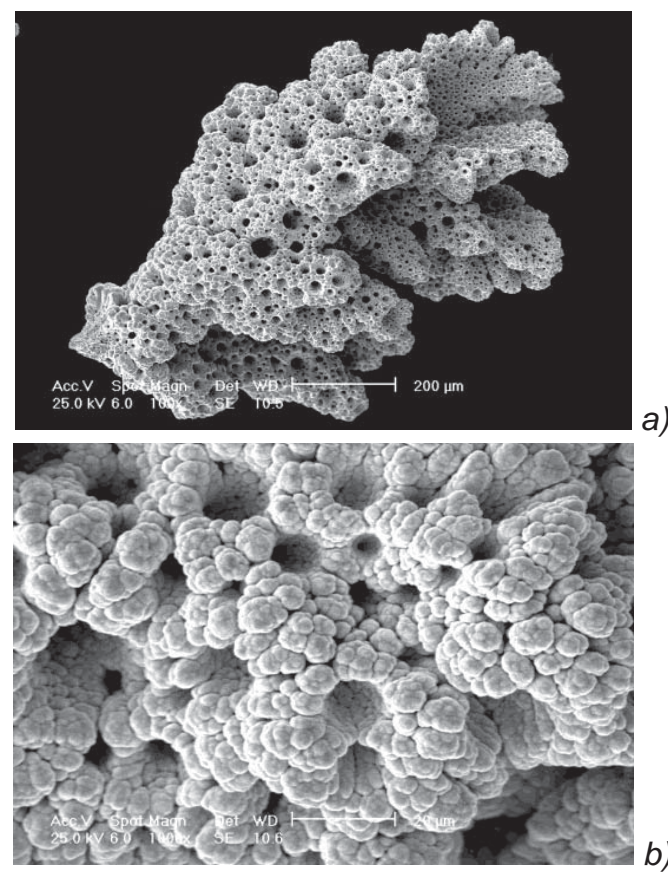

Figure 3. Morphology of the spongy-like Ni particle obtained by galvanostatic electrolysis at a current density of $1265 \mathrm{~mA} \mathrm{~cm}^{-2}$ from the chloride electrolyte

Slika 3. Morfologija sunđeraste čestice nikla dobijene galvanostatskom elektrolizom na gustini struje od $1265 \mathrm{~mA} \mathrm{~cm}^{-2}$ iz hloridnog elektrolita

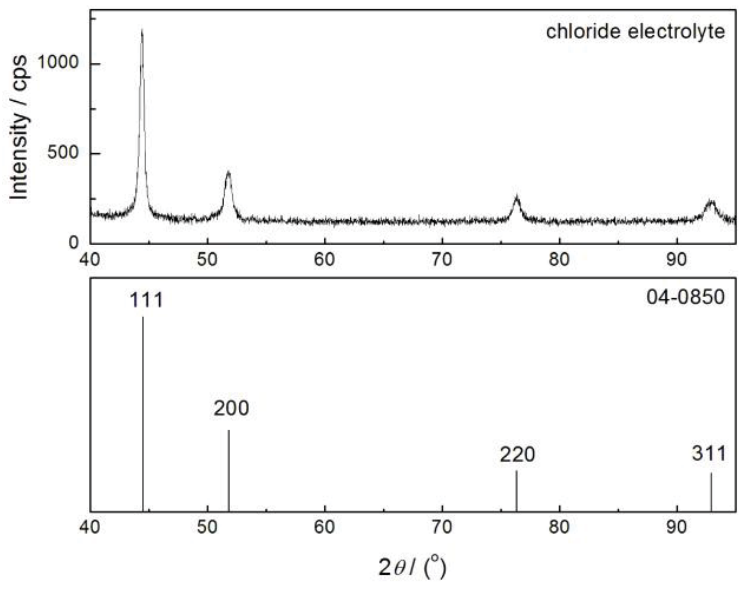

Figure 4. The XRD pattern of Ni particles obtained by galvanostatic electrolysis at a current density of $1265 \mathrm{~mA} \mathrm{~cm}^{-2}$ from the chloride electrolyte, and $\mathrm{Ni}$ standard (04-0850)

Slika 4. Rendgenogram čestica nikla dobijenih galvanostatskom elektrolizom na gustini struje od $1265 \mathrm{~mA} \mathrm{~cm}^{-2}$ iz hloridnog elektrolita, i Ni standard (04-0850)

It can be seen from Table 3 that the peak intensity ratios for $\mathrm{Ni}$ were very close to those for the standard established for randomly distributed grains [25].
Table 4. The values of R, TC and RTC, obtained for Ni particles produced by electrodeposition from chloride electrolyte at a current density of $1265 \mathrm{~mA} \mathrm{~cm}^{-2}$; s - Ni standard)

Tabela 4. Vrednosti R, TC i RTC koeficijenata dobijenih za Ni čestice proizvedene elektrohemijskim taloženjem iz hloridnog elektrolita na gustini struje od $1265 \mathrm{~mA} \mathrm{~cm}^{-2} ; \mathrm{s}-\mathrm{Ni}$ standard)

\begin{tabular}{|c|c|c|c|c|}
\hline $\begin{array}{c}\text { Plane } \\
(h k l)\end{array}$ & $R$ (in \%) & $\begin{array}{c}R_{\mathrm{s}} \text { (in } \\
\%)\end{array}$ & $T C$ & $\begin{array}{c}R T C \text { (in } \\
\%)\end{array}$ \\
\hline$(111)$ & 56.9 & 54.6 & 1.04 & 26.1 \\
\hline$(200)$ & 19.6 & 23.0 & 0.85 & 21.3 \\
\hline$(220)$ & 12.2 & 11.5 & 1.06 & 26.5 \\
\hline$(311)$ & 11.3 & 10.9 & 1.04 & 26.1 \\
\hline
\end{tabular}

The very close values of the peak intensity ratios to those for $\mathrm{Ni}$ standard (Table 3 ), as well as the $T C(h k l)$ values about 1 and $R T C(h k l)$ values about $25 \%$ (Table 4) clearly indicate the absence of the preferred orientation in the spongy-like particles, i.e. the existence of random orientation of crystallites in them.

\subsection{Discussion of the presented results}

The larger ratio of crystallites oriented in the (111) plane in $\mathrm{Pb}$ and Ni particles in relation to the other planes can be ascribed to a lower surface energy $(\gamma)$ for this plane than the values for the other planes [27, 28]. Namely, it is well known that the values of surface energy follow the trend: $\gamma_{111}<\gamma_{100}<\gamma_{110}$. However, although crystallites were dominantly oriented in the (111) plane, $\mathrm{Pb}$ and $\mathrm{Ni}$ particles showed the different preferred orientation. The dendritic $\mathrm{Pb}$ particles obtained from all three types of electrolytes showed the strong (111) preferred orientation. On the other hand, the crystallites of $\mathrm{Ni}$ in the spongy-like particles were random oriented. This random orientation can be ascribed to the existence of the spherical morphology in the spongy-like particles, as already observed in the case of silver particles obtained by electrolysis from the ammonium electrolyte and by chemical reduction with hydrazine [18].

The various morphologies of $\mathrm{Pb}$ and $\mathrm{Ni}$ particles with strong consequences on crystal orientation can be explained from electrochemical point of view on the basis of different affiliation of these metals in Winand's classification of metals [13]. The processes of $\mathrm{Pb}$ electrodeposition belong to the fast electrochemical processes characterized by the very high exchange current density $\left(j_{0} \rightarrow \infty\right)$, and by the high overpotential for hydrogen discharge (Class I, so-called normal metals). This characteristic enabled the formation of $\mathrm{Pb}$ powder particles at small overpotentials, as already observed in this investigation (Fig. 1). On the other hand, $\mathrm{Ni}$ belongs to the group of metals characterized by the low values of both exchange 
current density and overpotential for hydrogen evolution (Class III, inert metals). This means that electrodeposition of metals from this group occurs together with hydrogen evolution through whole range of current densities and potentials. As a result of vigorous hydrogen evolution, dendritic growth is inhibited, and the spongy-like particles like those shown in Fig. 3 are formed.

Hence, the decrease of the rate of electrochemical process was accompanied by the strong change of crystal structure from the strong (111) preferred orientation for $\mathrm{Pb}$ dendrites to almost random orientation in approximately spherical grains observed in $\mathrm{Ni}$ spongy-like particles. The obtained results were in a good agreement with those observed by $\mathrm{Ag}$ electrodeposition from various electrolytes and under various conditions of electrolysis [18, 19]. When the nitrate electrolyte was used for silver electrodeposition, Ag behaved as the normal metal. The needle-like and 2D fern-like dendrites with a (111) preferred orientation were then formed [18, 19]. However, $\mathrm{Ag}$ is transferred into the group of the intermediate metals with use of the ammonium electrolyte, and then the pine-like dendrites constructed from approximately spherical grains were formed. The XRD analysis of the pine-like dendrites showed that crystallites of $\mathrm{Ag}$ in them were mostly random oriented. The crystal structure is strictly determined by morphology of the particles and it is no dependent on regime of electrolysis, because the similar correlations between morphologies of the particles and the crystal orientation were obtained for $\mathrm{Ag}$ particles synthesized by both the potentiostatic and galvanostatic regimes of electrolysis [18, 19]. Anyway, the decrease of the rate of electrochemical process was accompanied by appearing of the spherical morphology in the particles and by the change of crystal orientation from the strong (111) preferred to random oriented crystallites.

The shape of $\mathrm{Pb}$ dendrites obeys to classical Wranglen's definition of dendrites [29]. According to Wranglen [29], a dendrite is a skeleton of a monocrystal and consists of a stalk and branches, thereby resembling a tree. The dendrite consisted only of the stalk and primary branches are referred as primary $(P)$ dendrite. If the primary branches in turn develop secondary branches, the dendrite is called secondary (S). The tertiary branches are developed from the secondary $(S)$, and then dendrite is called tertiary $(T)$, etc. The twodimensional (2D) dendrite refers to dendrites with branches that lie in the same plane as that of the primary stalk. Hence, the 2D dendrites obtained from the nitrate electrolyte belong to $(P)$ type, while $2 \mathrm{D}$ dendrites obtained from the acetate and hydroxide electrolytes belong to (S) type. Also, formation of tertiary branches is possible with use of hydroxide electrolyte [22, 23].

From all three electrolytes, $\mathrm{Pb}$ dendrites were produced at the overpotential outside the plateau of the limiting diffusion current density in the zone of instantaneous of dendritic growth [21-23]. From electrochemical point of view, a dendrite is defined as an electrode surface protrusion that grows under an activation control, while electrodeposition to the macroelectrode is predominantly under a diffusion control [1, 30-33]. Then, the tips of both primary and secondary branches grow under the activation control contributing to the fast increase in the current density with increasing the overpotential after the inflection point.

Although $\mathrm{Pb}$ and $\mathrm{Ag}$ (nitrate electrolytes) belong to the same group of metals, it is necessary to note that $R T C(111)$ values for $\mathrm{Pb}$ were larger than those observed for $\mathrm{Ag}[18,19]$. This can indicates that $\mathrm{Ag}$ is "slower" metal of $\mathrm{Pb}$, that is in an excellent agreement with electrochemical characteristics of these two metals. Namely, it is well known fact that the estimated $j_{0}$ values for $\mathrm{Pb}$ are larger than those for $\mathrm{Ag}$ [1], with the consequence that the beginning of diffusion control in the case of $\mathrm{Ag}$ is shifted to the higher overpotentials of electrodeposition. The predominant orientation of $\mathrm{Pb}$ crystallites in the (111) plane can be explained by different rates of growth of different crystal planes. For the fcc crystal lattice, due to different surface energies of crystal planes $[27,28]$, the electrodeposition rates follow a trend: $(110)>(110)>(111)[14,34]$. Following this fact, the (111) plane is denoted as a slow-growing plane, while (200), (220) and (311) planes belong to a group of fast-growing planes [35]. In the growth process, the (111) plane as the slowgrowing one survives causing the dominant orientation of $\mathrm{Pb}$ crystallites in this plane, while the fast-growing (200), (220) and (311) planes disappeared.

In the case of nickel, dendritic growth is inhibited by vigorous hydrogen evolution and the concept of "effective overpotential or potential" can be applied to explain formation of the spongy-like particles with the honeycomb-like structure. According to this concept $[1,26]$, when hydrogen evolution is vigorous enough, the electrodeposition process occurs at an overpotential which is effectively lower than that specified, and this overpotential is denoted as "effective" in a deposition process. The vigorous hydrogen evolution causes a strong stirring of the electrolyte in the near-electrode layer, leading to a decrease in the thickness of the diffusion layer, an increase in the limiting diffusion current density and a decrease in the degree of diffusion control of the electrodeposition process. From the morphological point of view, this means that the morphologies of metal deposits become similar to those obtained at 
some lower overpotentials at which hydrogen evolution does not occur or is very slow, that is confirmed in this case.

\section{CONCLUSION}

Lead and nickel in the powder form were synthesized via electrochemical route using the potentiostatic $(\mathrm{Pb})$ and galvanostatic $(\mathrm{Ni})$ regimes of electrolysis. Morphology of the obtained particles was characterized by scanning electron microscope (SEM), while their crystal structure was determined by the X-ray diffraction (XRD) analysis of the produced particles.

The 2D dendrites were formed by $\mathrm{Pb}$ electrolysis from the nitrate, acetate and hydroxide electrolytes. $\mathrm{Pb}$ dendrites formed from the acetate and hydroxide electrolytes were more branchy structure than those obtained from the nitrate electrolyte. Irrespective of the type of used electrolyte, all types of dendrites showed the strong (111) preferred orientation.

The spongy-like particles with almost randomly oriented crystallites in them were obtained by $\mathrm{Ni}$ electrolysis from the chloride electrolyte. The spongy-like particles were constructed from holes formed from the detached hydrogen bubbles surrounded cauliflower-like agglomerates of approximately spherical grains (the honeycomb-like structure).

Although the corresponding crystallites were predominately oriented in the (111) plane in all types of particles, $\mathrm{Pb}$ dendrites showed the strong (111) preferred orientation, while the spongy-like particles of $\mathrm{Ni}$ were random oriented. Correlation between morphology of the particles and their crystal structure was made following the division of metals on the normal, intermediate and inert metals based on their values of the exchange current density, melting point and overpotential for hydrogen discharge.

\section{Acknowledgments}

This work was supported by the Ministry of Education, Science and Technological Development of the Republic of Serbia under the research project: "Electrochemical synthesis and characterization of nanostructured functional materials for application in new technologies" (Project No. 172046).

\section{REFERENCES}

[1] K.I.Popov, S.S.Djokić, N.D.Nikolić, V.D.Jović (2016) Morphology of Electrochemically and Chemically Deposited Metals, Springer, New York, USA, p.p. 1368.

[2] M.Amiri, S.Nouhi, Y.Azizian-Kalandaragh (2015) Facile synthesis of silver nanostructures by using various deposition potential and time: A nonenzymatic sensors for hydrogen peroxide, Mater. Chem. Phys., 155, 129-135.

[3] M.G.Pavlović, K.I.Popov (2005) Metal Powder Production by Electrolysis, in Electrochemistry Encyclopedia (http://knowledge.electrochem.org/encycl/artp04-metalpowder.htm).
[4] G.Orhan, G.Hapci (2010) Effect of electrolysis parameters on the morphologies of copper powder obtained in a rotating cylinder electrode cell, Powder Technol., 201, 57-63.

[5] K.I.Popov, Lj.J.Pavlović, E.R.Ivanović, V.Radmilović, M.G.Pavlović (2002) The Effect of Reversing Current Deposition on the Apparent Density of Electrolytic Copper Powder, J. Serb. Chem. Soc., 67, 61-67.

[6] N.D.Nikolić, G.Branković, M.G.Pavlović (2012) Correlate between morphology of powder particles obtained by the different regimes of electrolysis and the quantity of evolved hydrogen, Powder Technol., 221, 271-277.

[7] S.J. Banik, R.Akolkar (2015) Suppressing Dendritic Growth during Alkaline Zinc Electrodeposition using Polyethylenimine Additive, Electrochim. Acta, 179, 475-481.

[8] R.K.Nekouie, F.Rashchi, N.N.Joda (2013) Effect of organic additives on synthesis of copper nano powders by pulsing electrolysis, Powder Technol., 237, 554-561.

[9] N.D.Nikolić, Lj.J.Pavlović, M.G.Pavlović, K.I.Popov (2008) Morphologies of electrochemically formed copper powder particles and their dependence on the quantity of evolved hydrogen, Powder Technol., 185,195-201.

[10] V.D.Jović, V.Maksimović, M.G.Pavlović, K.I. Popov (2006) Morphology, internal structure and growth mechanism of electrodeposited $\mathrm{Ni}$ and Co powders, J. Solid State Electrochem.,10, 373-379.

[11] V.D.Jović, B.M.Jović, M.G.Pavlović (2006) Electrodeposition of $\mathrm{Ni}$, Co and Ni-Co alloy powders, Electrochim. Acta, 51, 5468-5477.

[12] V.D.Jović, B.M.Jović, V.M.Maksimović, M.G.Pavlović (2007) Electrodeposition and morphology of $\mathrm{Ni}, \mathrm{Co}$ and $\mathrm{Ni}-\mathrm{Co}$ alloy powders: Part II. Ammonium chloride supporting electrolyte, Electrochim. Acta, 52, 4254-4263.

[13] R.Winand (1994) Electrodeposition of metals and alloys - new results and perspectives, Electrochim. Acta, 39, 1091-1105.

[14] N.D.Nikolić, V.M.Maksimović, G.Branković, P.M. Živković, M.G.Pavlović (2013) Influence of the type of electrolyte on morphological and crystallographic characteristics of lead powder particles, J. Serb. Chem. Soc., 78, 1387-1395.

[15] R.K.Nekouei, F.Rashchi, A.A.Amadeh (2013) Using design of experiments in synthesis of ultra-fine copper particles by electrolysis, Powder Technol., 237, 165-171.

[16] R.Sivasubramanian, M.V.Sangaranarayanan (2015) A facile formation of silver dendrites on indium tin oxide surfaces using electrodeposition and amperometric sensing of hydrazine, Sens. Actuators B, 213, 92-101.

[17] A.Nevers, L.Hallez, F.Touyeras, J.Y.Hihn (2018) Effect of Ultrasound on Silver Electrodeposition: Crystalline Structure Modification, Ultrason. Sonochem., 40, 60-71.

[18] Lj.Avramović, M.M. Pavlović, V.M. Maksimović, M.Vuković, J.S.Stevanović, M.Bugarin, N.D. Nikolić (2017) Comparative Morphological and Crystallographic Analysis of Electrochemically- and Chemically-Produced Silver Powder Particles, Metals, 7, 160.

[19] Lj.Avramović, E.R.Ivanović, V.M.Maksimović, M.M. Pavlović, M.Vuković, J.S.Stevanović, N.D.Nikolić (2018) Correlation between crystal structure and 
morphology of potentiostatically electrodeposited silver dendritic nanostructures, Trans. Nonferrous Met. Soc. China.

[20] L.Ph.Berube, G.L.Esperance (1989) A Quantitative Method of Determining of the Degree of Texture of Zinc Electrodeposits, J. Electrochem. Soc., 136, 2314-2315.

[21] N.D.Nikolić, Dj.Dj.Vaštag, P.M.Živković, B.Jokić, G.Branković (2013) Influence of the complex formation on the morphology of lead powder particles produced by the electrodeposition processes, Adv. Powder Technol., 24, 674-682.

[22] N.D.Nikolić, Dj.Dj.Vaštag, V.M.Maksimović, G.Branković (2014) Morphological and crystallographic characteristics of lead powder obtained by electrodeposition from an environmentally friendly electrolyte, Trans. Nonferrous Met. Soc. China, 24, 884-892.

[23] N.D.Nikolić, K.I.Popov (2014) A New Approach to the Understanding of the Mechanism of Lead Electrodeposition, in Electrodeposition and Surface Finishing, Series: Modern Aspects of Electrochemistry, Vol. 57, S.S.Djokić, Ed., Springer, p.p. 85-132.

[24] N.D.Nikolić, S.I.Stevanović, M.G.Pavlović, G.Branković (2016) Fundamentalni aspekti procesa elektrohemijskog taloženja olova: Nukleacija i rast, Zaštita materijala, 57(1), 119-127.

[25] M.V.Mandke, S-H.Han, H.M.Pathan (2012) Growth of silver dendritic nanostructures via electrochemical route, CrystEngComm, 14, 86-89.

[26] N.D.Nikolić, K.I.Popov, Lj.J.Pavlović, M.G.Pavlović (2006) The effect of hydrogen codeposition on the morphology of copper electrodeposits. I. The concept of effective overpotential, J. Electroanal. Chem., 588, 88-98.
[27] R.Sivasubramanian, M.V.Sangaranarayanan (2013) Electrodeposition of silver nanostructures: from polygons to dendrites, CrystEngComm, 15, 20522056.

[28] Y.Xia, Y.Xiong, B.Lim, S.E.Skrabalak (2009) ShapeControlled Synthesis of Metal Nanocrystals: Simple Chemistry Meets Complex Physics?, Angew. Chem. Int. Ed., 48, 60-103.

[29] G.Wranglen (1960) Dendrites and growth layers in the electrocrystallization of metals, Electrochim. Acta, 2, 130-146.

[30] J.W.Diggle, A.R.Despić, J.O'M.Bockris (1969) The mechanism of the dendritic electrocrystallization of zinc, J. Electrochem. Soc., 116, 1503-1514.

[31] K.I. Popov, N.V. Krstajić, M.I. Čekerevac (1996) The mechanism of formation of coarse and disperse electrodeposits, Series: Modern Aspects of Electrochemistry, Vol. 30, R.E.White, B.E.Conway, J.O' M.Bockris, Eds., Plenum Press, New York, p.p. 261-312.

[32] K.I.Popov, N.D.Nikolić (2012) General Theory of Disperse Metal Electrodeposits Formation, in Electrochemical Production of Metal Powders, Series: Modern Aspects of Electrochemistry, Vol. 54, S.S.Djokić, Ed., Springer, p.p. 1-62.

[33] K.I.Popov, P.M.Živković, N.D.Nikolić (2016) Electrochemical aspects of formation of dendrites, Zaštita materijala, 57(1) 55-62.

[34] J.O`M.Bockris, A.K.N.Reddy, M.Gamboa-Aldeco (2000) Modern Electrochemistry 2A, Fundamentals of Electrodics, Kluwer Academic/Plenum Publishers, New York, USA, p. 1333.

[35] N.D.Nikolić, V.M.Maksimović, G.Branković (2013) Morphological and crystallographic characteristics of electrodeposited lead from the concentrated electrolyte, RSC Adv., 3, 7466-7471.

\section{IZVOD}

\section{KORELACIJA IZMEDJU ORIJENTACIJE KRISTALA I MORFOLOGIJE ELEKTROLITIČKI PROIZVEDENIH PRAŠKASTIH ČESTICA: ANALIZA GRANIČNIH SLUČAJEVA}

Čestice praha olova i nikla proizvedene su procesima elektrolize i okarakterisane skenirajućim elektronskim mikroskopom. Urađena je i rendgeno=strukturna analiza dobijenih čestica. Morfologije čestica olova i nikla su korelisane sa njihovom kristalnom strukturom na polukvantitativnom nivou određivanjem "Teksturnog koeficijenta" (TC) i "Relativnog teksturnog koeficijenta" (RTC). Dvodimenzionalne (2D) dendritične čestice olova različitog stepena razgranatosti dobijene su potenciostatskim režimom elektrolize iz nitratnog, acetatnog i hidroksilnog elektrolita. Čestice nikla sunđerastog oblika u čijoj strukturi se uočavaju rupe formirane odvajanjem mehurova vodonika okružene karfiolastim aglomeratima približno sferičnih zrna (struktura pčelinjeg saća) dobijene su galvanostatskim režimom elektrolize iz hloridnog elektrolita. Premda su kristaliti dominantno orijentisani u (111) ravni $i$ u česticama praha olova i nikla, analiza rendgenograma je pokazala njihove različite dominantne orijentacije. Svi tipovi olovnih dendritičnih čestica su pokazali strogu (111) dominantnu orijentaciju, dok kristaliti nikla u sunđerastim česticama su bili skoro slučajno orijentisani. Dobijeni rezultati su diskutovani sledeći Vinjadovu klasifikaciju metala na normalne, intermedijalne i inertne, zasnovane na njihovim vrednostima gustine struje izmene, tačke topljenja i prenapetosti za reakciju izdvajanja vodonika.

Ključne reči: elektroliza, prah, olovo, nikal, skenirajući elektronski mikroskop, rentgeno-strukturna analiza.

Naučni rad

Rad primljen: 30. 03. 2018.

Rad prihvaćen: 15. 04. 2018.

Rad je dostupan na sajtu: www.idk.org.rs/casopis

(c) 2018 Authors. Published by Engineering Society for Corrosion. This article is an open access article distributed under the terms and conditions of the Creative Commons Attribution 4.0 International license (https://creativecommons.org/licenses/by/4.0/) 